This journal is the official publication of Bangladesh Society of Physiologists (BSP)

Web URL: www.banglajol.info/index.php/JBSP

Abstracted /indexed in Index Copernicus, Director of Open Access Journal, Index Medicus for South East Asia Region, Google Scholar, 12OR, infobse index, Open J gate, Cite factor, Scientific indexing services

pISSN-1983-1213; e-ISSN-2219-7508

\title{
Article
}

Article information:

Received on December 2018

Accepted on March 2019

DOI: https://doi.org/10.3329/jbsp.v14i1.41997

Corresponding author:

Rahman F, Akhter QS. Department of Physiology, Dhaka Medical College, Dhaka.

E-mail: runanewlook@gmail.com

Cite this article:

Farhana Rahman, Qazi Shamima Akhter. Serum

Zinc and Copper Levels in Alopecia

J Bangladesh Soc Physiol 2019;14(1): 21-25

This article is open access licensed under CC BY NC SA which allows readers copy, distribute, display, and perform the work and make derivative works based on it only for noncommercial purposes.

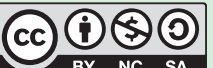

\section{Serum zinc and copper levels in} Alopecia

\author{
Farhana Rahman', Qazi Shamima Akhter ${ }^{1}$ \\ 1.Department of Physiology, Dhaka Medical College, Dhaka.
}

\section{Abstract}

Background: Emerging evidence suggests that trace elements such as zinc $\left(\mathrm{Zn}^{2+}\right)$ and copper $\left(\mathrm{Cu}^{2+}\right)$ are essential cofactor for multiple enzymes and have functional activities within hair follicles. So its deficiencies may cause hair loss. Objective: To assess the serum zinc and copper levels in alopecia. Methods: This cross sectional study was conducted in the Department of Physiology, Dhaka Medical College, Dhaka from January to December during 2017. Thirty five patients icluding both sexes with hair loss aged 18 to 45 years were study group and 35 ages and BMI matched healthy subjects were control group. Serum zinc and copper levels were estimated by flame atomic absorption spectrophotometry. For statistical analysis Unpaired Student's ' $t$ ' test and Chi square tests were performed. Results: Serum $\mathrm{Zn}^{2+}$ and $\mathrm{Cu}^{2+}$ levels were significantly $(p<0.001)$ lower in study group than those of control group. Conclusions: It was concluded that serum $\mathrm{Zn}^{2+}$ and $\mathrm{Cu}^{2+}$ deficiencies are associated with hair loss patients.

Keywords: Alopecia, zinc, copper.

Introduction

lopecia means any type of hair loss, thinning of hair or
baldness in any hairy region of the body. Hair loss is a
part of normal hair growth process. It is not a life threatening disease but causes psychological effects in most people ${ }^{1}$.

Alopecia can be classified as focal and diffuse alopecia. Focal alopecia can be categorized into non-scarring and scarring 
alopecia. Alopecia areata is the example of nonscarring hair loss. It is characterized by hair loss that range from single oval patch to multiple patches. Scarring alopecia is rare and usually caused by discoid lupus erythematosus. Diffuse alopecia can be categorized into telogen effluvium, female pattern and male pattern ${ }^{2}$. Male and female pattern hair loss is called androgenic alopecia due to altered metabolism of androgen ${ }^{3}$. Female pattern alopecia is characterized by thinning and reduction in hair density over the crown and frontal regions ${ }^{4}$.

Trace elements are essential cofactors for multiple enzymes and have important functional activities within hair follicles 5 . They perform various catalytic, structural and regulatory functions of our body ${ }^{6}$. The trace elements such as zinc $\left(\mathrm{Zn}^{2+}\right)$ and copper $\left(\mathrm{Cu}^{2+}\right)$ have much important role in the growth and development of hair ${ }^{5}$.

$\mathrm{Zn}^{2+}$ is an essential trace element with multiple roles in human nutrition. $\mathrm{Zn}^{2+}$ is required for functional activities in hair follicle and helps in hair follicle recovery. It maintains the oil secreting glands attached to hair follicles which maintain the sebum and prevent dryness of hair ${ }^{7,8} \cdot \mathrm{Zn}^{2+}$ deficiency actually lead to deterioration of protein structure that makes up the hair follicle. This weakening of follicles cause hair shedding and hair loss. Deficiency of $\mathrm{Zn}^{2+}$ impairs DNA and RNA production which is required for the normal division of hair follicle cells and developmental stage of hair growth ${ }^{9}$.

Copper $\left(\mathrm{Cu}^{2+}\right)$ participate in several cellular and physiological functions. Copper increase hair follicle size and produce thicker hair. $\mathrm{Cu}^{2+}$ also inhibit 5-Alpha Reductase enzyme which is important for conversion of testosterone to dihydrotestosterone (DHT). In $\mathrm{Cu}^{2+}$ deficiency, thereis excess formation of DHT. Dihydrotestosterone is the major factor in male pattern alopecia ${ }^{10,11}$.

Trace elements act at molecular level and are active at any minute concentration. So, small amount of trace element deficiency may cause alopecia. Different researchers and organizations of different countries performed study on serum $\mathrm{Zn}^{2+}$ and $\mathrm{Cu}^{2+}$ levels in hair loss patients. The gravity of this issue in Bangladeshi population is not yet known as there are less published data regarding this topic in our country. The present study is designed to assess the serum $\mathrm{Zn}^{2+}$ and $\mathrm{Cu}^{2+}$ levels and to find out their correlation with alopecia.

\section{Methods}

This cross sectional study was conducted in the Department of Physiology, Dhaka Medical College (DMC), Dhaka between January 2017 to December 2017. The protocol was approved by the research review and ethical committee, DMC. Thirty five subjects consists of both focal and diffuse hair loss, with age range 18 to 45 years included in the study and, were study group and 35 age- and BMI matched healthy subjects served as control. Patients were selected from Department of Dermatology and Venerology, DMC \& Hospital. To select subjects, Alopecia patients under treatment as well as chronic disease were excluded. After selection of the subjects, the nature, purpose and benefit of the study were explained to each subject in details and informed written consent was taken. Before taking blood pressure, detailed family and medical history were taken. Anthropometric measurement of the subjects was done. All the information was recorded in a data schedule. With aseptic precaution, $5 \mathrm{ml}$ of venous blood were collected from ante-cubital vein by $10 \mathrm{cc}$ disposable test tube and allowed to clot on in slanted position for $30 \mathrm{~min}$ and the centrifused at a rate of 3000 rpm for 15 minutes. After that, separated supernantant serum was aliquoted collected in labeled eppendroptube and preserved at $-20^{\circ} \mathrm{C}$ until analyses. Serum zinc level and copper levels were estimated by using atomic absorption flame photometry in the Department of Soil, Water and Environment, University of Dhaka. Statistical analyses were performed using computer based 
statistical program SPSS (Statistical Package for Social Sciences) Version 16. Results were explressed as mean and standard deviation (mean \pm SD). Unpaired Student's ' $t$ ' test and Chi-square test were carried as applicable.

Results

Mean $( \pm$ SD) of age, BMI systolic and diastolic blood pressure were shown in Table I. The parameters did not show statistical difference between the study group and the controls. Male and female distribution in the two groups did not show any significant association $(p=0.231)$ (Table I). Mean $\pm \mathrm{SD}$ serum $\mathrm{Zn}^{2+}$ and $\mathrm{Cu}^{2+}$ in the alopecia group were significantly lower $(\mathrm{p}<0.001)$ compared to the controls (Table II). Both male and female in the alopecia group had significantly $(\mathrm{p}<0.001)$ lower serum zinc and serum copper compared to the corresponding controls (Table III).

Table I: General characteristics of the subjects in both groups $(\mathrm{N}=70)$

\begin{tabular}{lcc}
\hline & Alopecia $(\mathrm{n}=35)$ & Control $(\mathrm{n}=35)$ \\
\hline Age $(\mathrm{yrs})$ & $25.37 \pm 6.84$ & $27.14 \pm 5.82$ \\
Sex $(\%)^{\mathrm{b}}$ & & \\
Male & $14(40 \%)$ & $19(54.3 \%)$ \\
Female & $21(60 \%)$ & $16(45.7 \%)$ \\
BMI $\left(\mathrm{kg} / \mathrm{m}^{2}\right)^{\mathrm{a}}$ & $23.50 \pm 3.45$ & $24.83 \pm 3.05$ \\
$\mathrm{SBP}(\mathrm{mmHg})^{\mathrm{a}}$ & $114.43 \pm 12.29$ & $112.71 \pm 12.78$ \\
$\mathrm{DBP}(\mathrm{mmHg})^{\mathrm{a}}$ & $78.74 \pm 10.18$ & $78.00 \pm 9.72$ \\
\hline
\end{tabular}

Sex distribution has been shown in number and percentage. All other results are expressed as mean $\pm \mathrm{SD} . P$ value $<0.005$ was accepted as level of significance. $a=$ Unpaired Student's ' $t$ ' test $(a), b=$ chi-Square test, $N=$ total number of subjects, $\mathrm{n}=$ number of subjects in each group, BMI= Body mass index. SBP $=$ systolic blood pressure, $\mathrm{DBP}=$ Diastolic blood pressure.

Table II: Serum zinc and copper level of the study subjects $(\mathrm{N}=70)$

\begin{tabular}{lcc}
\hline Parameters & Alopecia $(\mathrm{n}=35)$ & Control $(\mathrm{n}=35)$ \\
\hline Serum zinc $(\mu \mathrm{g} / \mathrm{dl})$ & $75.41 \pm 9.47^{* * *}$ & $99.97 \pm 7.72$ \\
Serum copper $(\mu \mathrm{g} / \mathrm{dl})$ & $74.55 \pm 9.65^{* * *}$ & $100.23 \pm 10.95$ \\
\hline
\end{tabular}

Results were expressed as mean $\pm \mathrm{SD}$, Unpaired Student's ' $t$ ' test was performed to compare between the groups. ${ }^{* * *}=$ patients $\mathrm{Vs}$ control group, $\mathrm{N}=$ total number of subjects, $\mathrm{n}=$ number of subjects in each group. $* * *=P<0.001$,

Table III: Serum $\mathrm{Zn}^{2+}$ and $\mathrm{Cu}^{2+}$ levels between subjects with alopecia and controls between male and female

\begin{tabular}{lccccc}
\hline Parameters & \multicolumn{2}{c}{ Male } & & \multicolumn{2}{c}{ Female } \\
\cline { 2 - 3 } \cline { 5 - 6 } & Alopecia $(\mathrm{n}=14)$ & Control $(\mathrm{n}=16)$ & & Alopecia $(\mathrm{n}=21)$ & Control $(\mathrm{n}=19)$ \\
\hline $\mathrm{S} . \mathrm{Zn}(\mu \mathrm{g} / \mathrm{dl})$ & $68.325 \pm 8.48^{* * *}$ & $100.81 \pm 9.37$ & & $78.80 \pm 8.87^{* * *}$ & $99.25 \pm 6.13$ \\
S. $\mathrm{Cu}(\mu \mathrm{g} / \mathrm{dl})$ & $67.09 \pm 6.94^{\# \# \#}$ & $102.06 \pm 11.13$ & & $80.77 \pm 6.88^{\# \# \#}$ & $99.13 \pm 11.23$ \\
\hline
\end{tabular}

Results were expressed as mean \pm SD. Statistical analysis was done byUnpairedStudent's ' $t$ ' test (a) for comparison between groups. $\mathrm{N}=$ total number of subject. $* * *=$ serum $\mathrm{Zn}^{2+}$ level of alopecia $\mathrm{Vs}$ control in both male and female, ${ }^{\# \#}=$ serum $\mathrm{Cu}^{2+}$ level of alopecia Vs control in both male and female. ${ }^{* * *}=P<0.001,{ }^{\# \#=P<0.001}$ 
Discussion

In the present study, mean serum zinc and copper levels were lower in patients with alopecia than that of controls. Again significantly lower serum $\mathrm{Zn}^{2+}$ and $\mathrm{Cu}^{2+}$ levels were observed in male and female in patients with alopecia than male and female of controls. This result is similar to others 6,7,10. There is reported value of $\mathrm{Zn}^{2+}$ and $\mathrm{Cu}^{2+}$ are $99.97 \mu \mathrm{g} / \mathrm{dl}$ and $100.23 \mu \mathrm{g} / \mathrm{dl}$ in group of healthy individuals. But in this study values of $\mathrm{Zn}^{2+}$ and $\mathrm{Cu}^{2+}$ wer lower $75.41 \mu \mathrm{g} / \mathrm{dl}$ and $74.55 \mu \mathrm{g} /$ $\mathrm{dl}$ in alopecia which is attributed to nutritional deficiency and environmental pollution. Literature review suggested that zinc acts as a coenzyme in 4 stages in the cell cycle that is G1, S, G2 and Mitosis. In G1 stage, RNA synthesis, protein synthesis occurs and cell size increases. DNA is synthesized in S stage. In G2 stage, cell division and in mitosis nuclear division occurs. In all these metabolic process zinc acts as a coenzyme. As DNA and RNA are needed for hair follicle cell division and optimal hair growth during anagen stage of hair growth cycle, as a consequences zinc deficiency, arrest of hair follicle cell division occur leading to hair loss 9 .

Copper ion deficiency leads to hair loss due to excessive formation of Dihydrotestosterone (DHT) and inhibition of proliferation of dermal fibroblast. DHT is formed from testosterone by the action of 5-alpha reductase enzyme. Copper ions are potent inhibitors of this 5-alpha reductase enzyme and block DHT formation. In copper ion deficiency, there is excess formation of DHT that binds to the androgen receptors on the hair follicles to form a hormone receptor complex. This complex promotes the transcription of androgen dependent gene and progressively shortens the follicle's anagen phase and lengthen the telogen phase. The net result is shrinkage of hair follicle size during the anagen phase leading to thinning of growing hair. Dermal fibroblast is responsible for formation of vascular endothelial growth factor (VEGF). Copper ion facilitates new capillary formation by stimulating this dermal fibroblast. In copper deficiency, this proliferation does not occur. So, there is decreased blood supply and growth of hair follicle leading to in inadequate hair synthesis ${ }^{3,11,12}$.

\section{Conclusion}

From the results of the study, it can be concluded that lower serum zinc and copper level may be associated with Alopecia irrespective of gender. So estimation of serum $\mathrm{Zn}^{2+}$ and $\mathrm{Cu}^{2+}$ level might be helpful for proper management of alopecia.

\section{Conflict of Interest None}

Acknowledgement The authors acknowledge the Department of Soil, Water and Environment, University of Dhaka for their kind cooperation to carry out the laboratory investigations.

\section{References}

1. NordquvistC.What is hair loss (alopecia)? What is baldness? [Internet]. SanfordBurnham:Medical Research Institute in La Jolla, CA. [updated 2015 Feb 9; cited 2017Feb 9]. Available from: http:// www.medicalnewstoday. Com/articles/70957.php.

2. Mounsey AL and Reed SW. Diagnosing and treating hair loss. Am Acad of FamPa 2009;80(4):356-62.

3. Roem NR, Tarib F, NN, Wasodo, Patellongi I, Bukhair A, Nafie NL.Hair's zinc level onandrogenic alopecia. Am J of Clin and Exp Med 2016;4(5):12933.

4. Dinh QQ and Sinclair R. Female pattern hair loss: Current treatmentconcepts. Clin Interv in $\mathrm{Ag}$ 2007;2(2):189-99.

5. Dastgheib L, Mostafavi-Pour Z, Abdoraazagh AA, Khoshdel Z, SadatiMS,Ahrari I, AhrariS, GhavipishehM.Comparison of $\mathrm{Zn}, \mathrm{Cu}$ and Fecontent in hair and serum in alopeciaareata patients withnormal group. Dermatol Res and pract 2014; 2014: 1-5

6. El- Ashmawy AA andKhedr AM. Some trace elements level in alopeciaareata. Egypt Dermatol Online J 2013;9(1): 1-11.

7. Hamad WAM, Said AF, El Hamid AAA.Role of some trace elements inthepathogenesisoftelogen 
effluvium in Egyptian female. Egypt Women Dermatol Soc 2010; 7: 44-48.

8. Kil MS, Kim CW, Kim SS. Analysis of serum zinc and copper concentrations in hair loss. Ann Dermatol 2013; 25 (4): 405-09.

9. Falchuk KH, Fawcett DW, Vallee BL. Role of zinc in cell division of Euglena Gracilis. J Cell Sci 1975; 17: $57-78$
10. Lee SY, Nam KS, Seo YW, Lee SJ, Chung H. Analysis of serum zinc and copper levels in alopecia areata. Ann of Dermatol 1997; 9(4): 239-41.

11. PickartL. Improving hair growth with skin remodeling copper peptides. Dermatol 2004;3(6).

12. Pyo HK, Yoo HG, Won CH, Lee SH, Kang YJ, Eun HC, Cho KH, Kim KH. The effect of Tripeptidecopper complex on human hair growth in vitro. Arch Pharm Res 2007; 30(7):834-39. 